\begin{tabular}{|l|l|l|}
\hline \multicolumn{2}{|c|}{ PublisherInfo } \\
\hline \hline PublisherName & $:$ & BioMed Central \\
\hline \hline PublisherLocation & $:$ & London \\
\hline \hline PublisherImprintName & $:$ & BioMed Central \\
\hline \hline
\end{tabular}

\title{
Effect of anti-c5a on thymocyte apoptosis
}

\begin{tabular}{|l|l|l||}
\hline \multicolumn{2}{|c|}{ ArticleInfo } \\
\hline \hline ArticleID & $:$ & 116 \\
\hline \hline ArticleDOI & $:$ & $10.1186 /$ ar-2001-66878 \\
\hline \hline ArticleCitationID & $:$ & 66878 \\
\hline \hline ArticleSequenceNumber & $:$ & 73 \\
\hline \hline ArticleCategory & $:$ & Paper Report \\
\hline \hline ArticleFirstPage & $:$ & 1 \\
\hline \hline ArticleLastPage & $:$ & 3 \\
\hline \hline & & RegistrationDate : 2001-1-23 \\
\hline ArticleHistory & $:$ & OnlineDate \\
\hline \hline ArticleCopyright & $:$ & Biomed Central Ltd2001-1-23 \\
\hline \hline ArticleGrants & $:$ & \\
\hline \hline ArticleContext & $:$ & 130753311 \\
\hline \hline
\end{tabular}




\section{Keywords}

Apoptosis, C5a, sepsis, thymocytes

\section{Context}

Lymphocytes, especially immature thymocytes, appear to undergo apoptosis vigorously during sepsis, resulting in a dramatic reduction in thymus weight. Complement activation during sepsis results in elevated levels of $\mathrm{C} 3 \mathrm{a}$ and $\mathrm{C} 5 \mathrm{a}$ in rats, primates and humans, and in vivo blockade of $\mathrm{C} 5 \mathrm{a}$ improves survival of rats and primates with sepsis. This study addresses the effect of C5a blockade on thymocyte apoptosis in an experimental model of sepsis in rats.

\section{Significant findings}

In this experimental model of sepsis in rats, measures of thymocyte apoptosis (thymic weight loss, DNA fragmentation, caspase- $3,-6$, and -9 activation, cytochrome release, and reduction in Bcl-XL levels) were dramatically reduced in rats treated with rabbit anti-rat C5a, compared with these parameters in control rats, which received pre-immune rabbit IgG. There was no difference in expression of BAX or Bcl-2 in the rats with cecal ligation versus sham-operated controls. Sepsis produced an increase in nuclear transcription of NF-?B, which was unaffected by C5a blockade.

\section{Comments}

The fact that C5a blockade prevents thymus apoptosis in this model suggests that C5a is critical to the apoptotic process in sepsis. Paradoxically, although C5a plays a critical role in host defense, in sepsis it appears to harm the host by promoting apoptosis of lymphocytes. Since C5a stimulates the synthesis and release of proinflammatory cytokines such as TNF-a, IL-1?, IL-6 and IL-8 from human leukocytes, it seems likely that C5a promotes apoptosis through cytokine expression. These findings are potentially significant in view of the development of a humanized monoclonal antibody to human C5 which is currently under investigation in the treatment of rheumatoid arthritis and lupus. The mouse version of 
this monoclonal antibody appears to be effective in the treatment of murine lupus. The therapeutic effect of an agent which inhibits apoptosis might seem paradoxical in lupus, a disease in which apoptosis is thought to be defective.

\section{Methods}

Experimental sepsis was induced in male Long-Evans rats by ligation and perforation of the cecum. The rats were then sacrificed at different intervals.

\section{References}

1. Guo R-F, Huber-Lang M, Wang X, Sarma V, Padgaonkar VA, Craig RA, Riedemann NC, McClintock SD, Hlaing T, Shi MM, Ward PA: Protective effects of anti-C5a in sepsis-induced thymocyte apoptosis. J Clin Invest. 2001, 106: 1271-1280. 